\title{
Embedding Theory in Corporate Identity through the Social Construction Lens
}

\author{
Olutayo Otubanjo ${ }^{1}$ \\ ${ }^{1}$ Lagos Business School, Pan-African University, Lagos, Nigeria \\ Correspondence: Olutayo Otubanjo, Lagos Business School, Pan-African University, Km 22 Lekki Epe \\ Expressway, Ajah, Lagos, Nigeria. Tel: 234-808-608-6816. E-mail: totubanjo@lbs.edu.ng
}

Received: August 20, 2012 Accepted: September 19, 2012 Online Published: October 22, 2012

doi:10.5539/ijbm.v7n22p62 URL: http://dx.doi.org/10.5539/ijbm.v7n22p62

\begin{abstract}
This paper strengthens the concept of corporate identity by embedding it with the social constructionist theory. This objective is accomplished through the integration of core arguments within Berger and Luckman's social constructionist epistemology with important viewpoints present within a variety of corporate identity models. Importantly, the outcome of the integration exercise reveals seven thematic points of interconnectivity between social constructionism and corporate identity. It is hoped that these points on interconnectivity would lay a foundation for further studies on how the concept of corporate identity can be further strengthened with theory.
\end{abstract}

Keywords: corporate communications, corporate identity, corporate personality, social construction, ongoingness

\section{Introduction}

Academic work on corporate identity concept is bereft of a social science theory. This paper aims to fill this gap by offering the social constructionist theory as a lens for viewing the concept of corporate identity. In order to do so, this paper has been divided into six main paragraphs. The first opens with a review of social constructionist philosophy. This followed by a review of influential texts on corporate identity. The links between social constructionism and corporate identity are drawn in the fourth paragraph. The paper ends with a summary of the issues discussed.

\section{Social Construction}

Social construction phenomenon popularised by Berger and Luckmann (1966) aims to unearth the manner in which individuals and groups contribute to the formation of professed reality (Berger and Luckmann, 1966). Social constructionists argue that 'objects' of thought and belief relating to everyday life emanates from the deep beliefs in societies. Social construction therefore aims to examine the ways that social phenomena (i.e beliefs) and trends are produced, shaped, entrenched and made into custom (Hacking, 2010). By social construction of reality Berger and Luckmann (1966) refers to enduring dynamic process, created and recreated by people given their interpretations and knowledge of such changing processes within the society.

Berger and Luckmann observed that all knowledge, including the most basic, taken-for-granted common sense knowledge of everyday reality, is derived from social interactions (Gergen, 2010). In everyday life, individuals relate upon the common belief that their views of reality are connected (see Shotter, 1993a; 1993b) and as they act upon this belief reinforcement of what is conceived as reality takes places (Searle, 1995). Thus, since the common belief of reality is negotiated and created, individuals, human typifications, significations and firms are presented as part of an objective reality. It is on this basis that reality is socially constructed (Hacking, 2010).

As stated earlier, social construction is originally a social science and humanities discipline but has been adopted in business studies (Edvardsson et al, 2011; Orlitzky, 2011; Matsui, 2009; Witt, 2010; Wu, 2009; Gupta, 2001; Palmer and Ponsonby, 2001; Morgan and Pritchard, 1998). It is an intellectual advancement on other meta-theoretical perspectives popular in marketing research and the author's approach of this research is heavily influenced by (mainly European) perspectives from critical and post structuralist (Gergen, 2010; Potter and Wetherell, 1987; Brunner, 1990; Edwards and Potter, 1992; Miller and Hoogstra, 1992; Banister et al., 1994; Harré and Gillett, 1994; Fairclough, 1995; Harre and Sterans 1995; Fox and Prilleltensky, 1997; Bayer and Shotter 1998; Potter, 1998; Wetherell, 1998). The social construction theory (partnered by the reflective and 
intentional theories) belongs to a body of knowledge referred to as the theories of cultural representation (Hall, 1999).

Unfortunately it is plagued by little understanding. It has been described in business studies discipline as a fundamentally a working assumption about firms and stakeholders and their interdependence in the business environment. Language and other rhetorical devices are used to grasp at forms and structures that are imagined will serve in one way or another. Social construction amplifies the silence roaring in mainstream business discourse, a silence of complicity and imagined self-interest (Hackley, 2001). Social construction is concerned with language as a cognitive force in the social organisation of business institutions and the construction of identity.

\subsection{Berger and Luckmann's (1966) Social Construction Epistemological Process}

In the paragraphs that follow, Berger and Luckmann's (1966) epistemology is broken down into a developmental process consisting a series of interrelated actions. This approach, which provides a logical and sequential arrangement of how social construction epistemology functions is valuable in that it gives easy, visual, clear, workable and deeper insight into the working mechanisms of Berger and Luckmann's (1966) epistemology. The process approach to this epistemology clarifies the interrelationship and interconnectivity that subsist within Berger and Luckmann's (1966) work. Also it allows a grasp and easier interpretation of how various interrelated actions within Berger and Luckmann's (1966) epistemology function cohesively. The process provides a deeper understanding of how the expression of reality (the end product of social construction) comes about. For according to Berger and Luckmann (1966, p.72), "it is impossible to understand an institution adequately without an understanding of the historical process in which was produced".

Stage one: joint and ongoing production of human environment: Berger and Luckmann's (1966) work addresses the collective production of the environment. The production of meaning is sustained through ongoing interactions, which triggers psychological formations, typifications or mental representations of actions among social actors within the social fabric. Figure 1 illustrates how mental typifications emerge through the interaction of actors within the societal fabric. Put another way, it is impossible for man alone to develop socially in isolation of the society. Man alone cannot produce the environment. The production of the environment is a collective social enterprise involving the totality of social cultural and psychological formations of social actors. The solitary man is tantamount to being an animal. It is natural that once born, man enters the realm of social actors. Therefore, man's specific humanity and socio cultural wellbeing are unavoidably interrelated and interlinked.

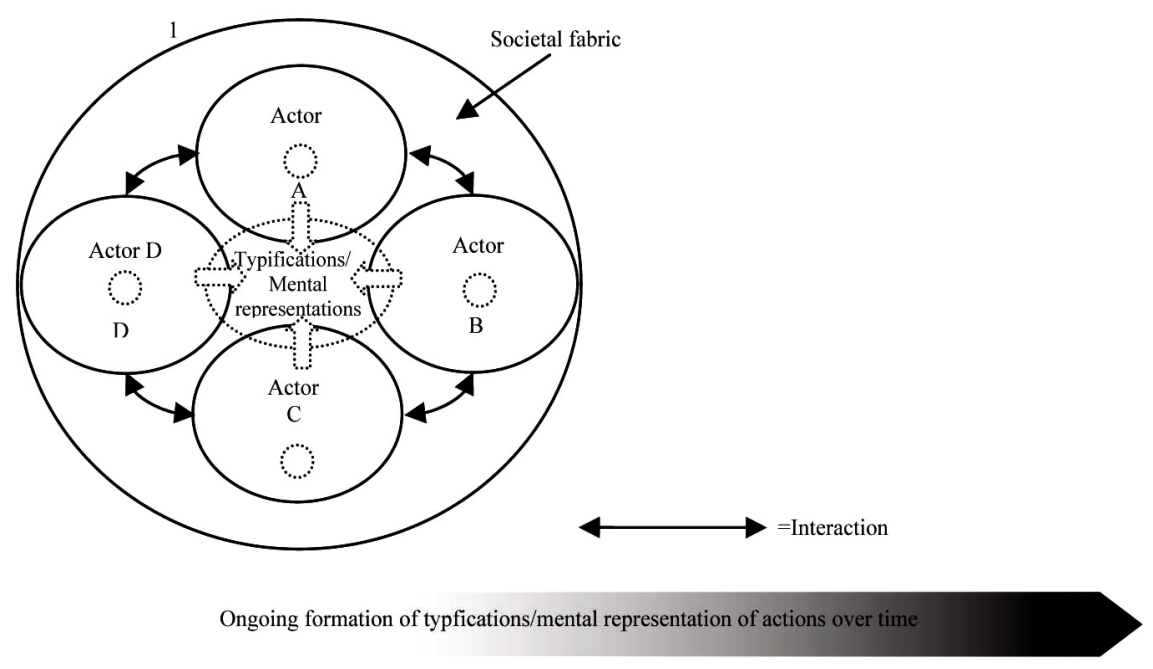

Figure 1. Human interactions leading to typifications over time

Designed by author but developed based on Berger and Luckmann's (1966) work

For according to Berger and Luckmann (1966, p. 69) "Homo sapiens is always, and in the same measure, homo socius". In essence, the production of the human environment rests primarily on the shoulders of social actors 
who use conceptual systems (within the society), language and other representational means to produce the human environment or more precisely to interpret the world and produce meanings, to make the human society meaningful. These conceptual systems (together with language and other representational means) are drawn and deployed by social actors to express ideas and communicate meaningfully about the world to groups.

Stage two: human existence takes place in the context of order, direction and stability: human existence or human conduct is founded on the pillars of order, direction and stability. Figure 2 illustrates how the notions of order, direction and stability sit as the basis of social fabric. The existing stability of human order is derived from two theoretical conceptions. First is that a given social order precedes any individual organismic development. Although world-openness is fundamental to man's biological make-up, it is however pre-empted by social order. Second, the notion of world-openness, which is essential to human existence, must be transformed into a relative world of closedness by social order. While it is difficult if not impossible for this reclosure to estimate the closedness of animal existence (given that it is humanly produced and thus having artificial character) it is nevertheless capable of marshalling direction and providing stability for most part of human conduct.

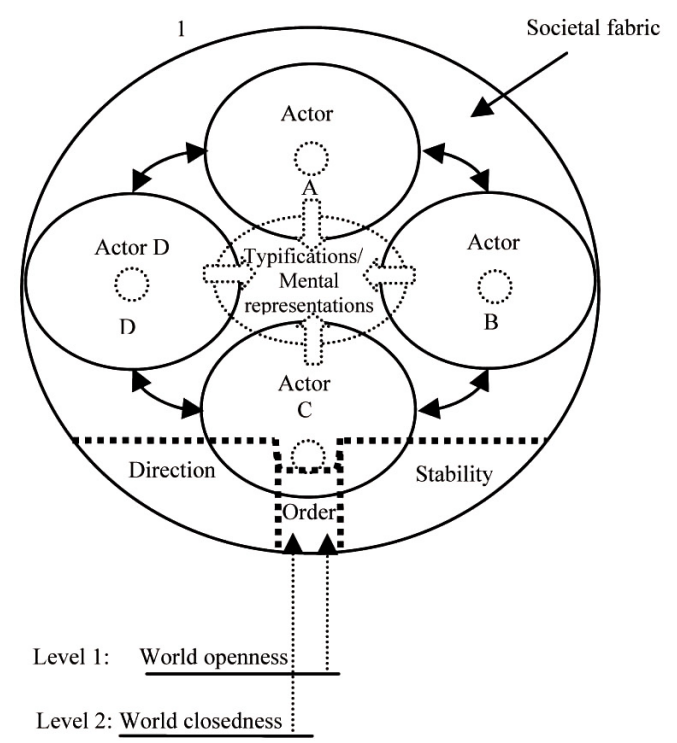

Ongoing formation of typfications/mental representation of actions over

Figure 2. Three pillars of human existence: order, direction and stability

Developed by author based on Berger and Luckmann's (1966) work

Social order as an ongoing human production: social order is a human product or an ongoing human production, created by man in the course of ongoing externalisation. Social order is not biologically derived from biological data nor is it drawn from man's natural environment. It is the outcome of ongoing and never-ending human activities and the result of past human activity. The phenomenon of social order subsists for as long as human activity continues. It is assumed that human being may not survive in a closed sphere of dormant and inactive interiority. Rather human beings must continuously and ongoingly externalise and embed themselves in activities. However, the innate instability of human organisms provokes the need for man to provide and develop a stable environment for his daily activities. Therefore, man, it is argued, must specialise and direct his drives. These biological issues are intrinsic for the successful creation of social order.

Stage four: ongoing activities are subject to habitualisation which produces meanings: All human actions that are repeated regularly and recurrently over a period of time become cast into a behavioural pattern - and this becomes a habit. The notion of habitualisation implies that human actions, which are repeated regularly be replicated with similar approach and with the same amount of economic effort. The repetitive nature of this theory is illustrated with three tiny circles in Figure 3. 


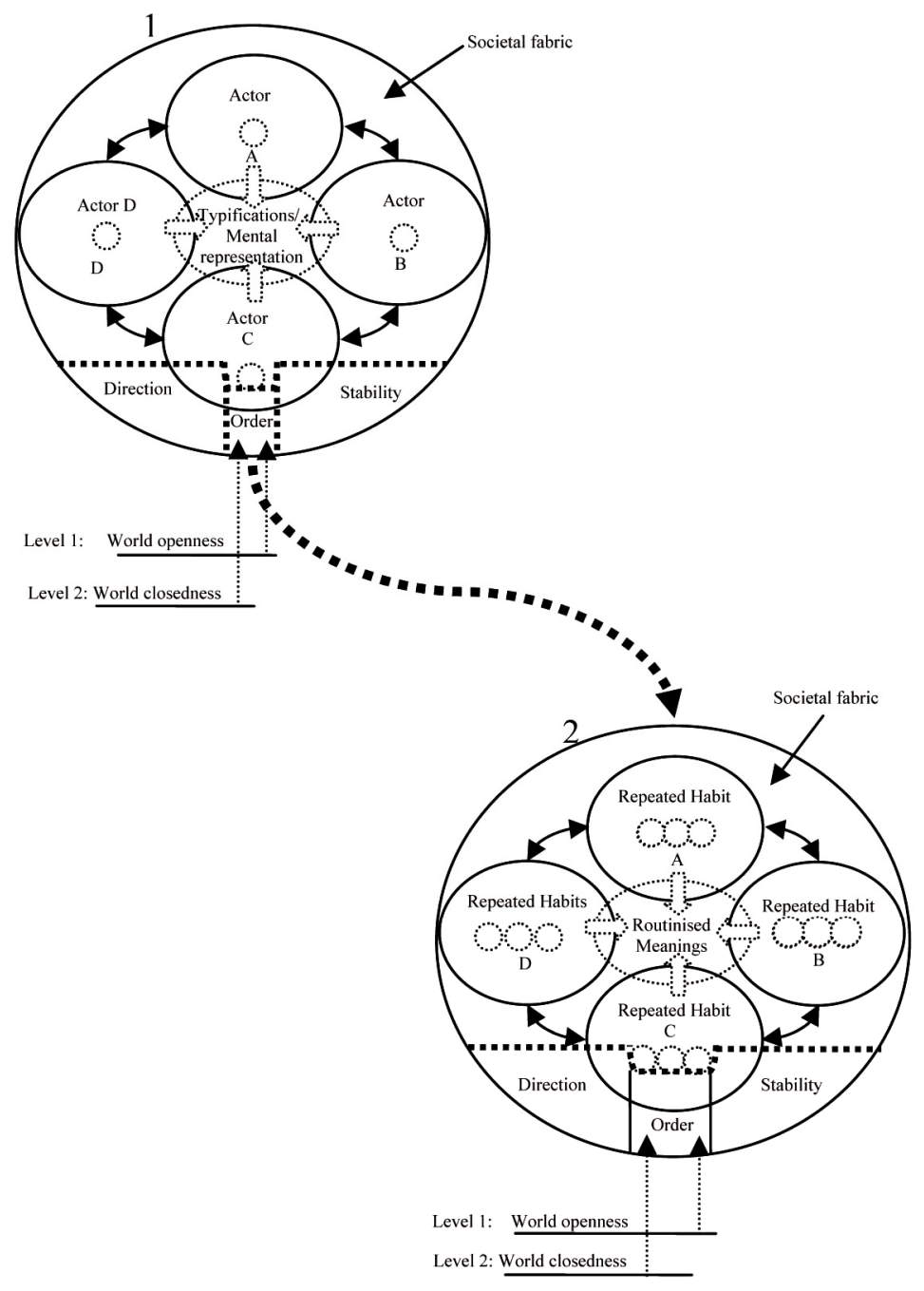

Ongoing production of routinesed meanings via habitualised actions over time

Figure 3. Production of routinised meanings through habitualised actions

Designed by author but developed based on Berger and Luckmann's (1966) work

Stage five: Institutionalisation of meanings via ongoing Reciprocal Typification of Habitualised Actions (RTHA): institutionalisation is the development of rules which guide social actors in specific circumstances (Berger and Luckmann, 1966). It emerges from ongoing reciprocal typification (i.e. institution) of habitualised actions (RTHA, see Figure 4 below) by actors overtime. Importantly, institutionalisation emphasises the reciprocity of institutional typifications and the typicality of actions. 


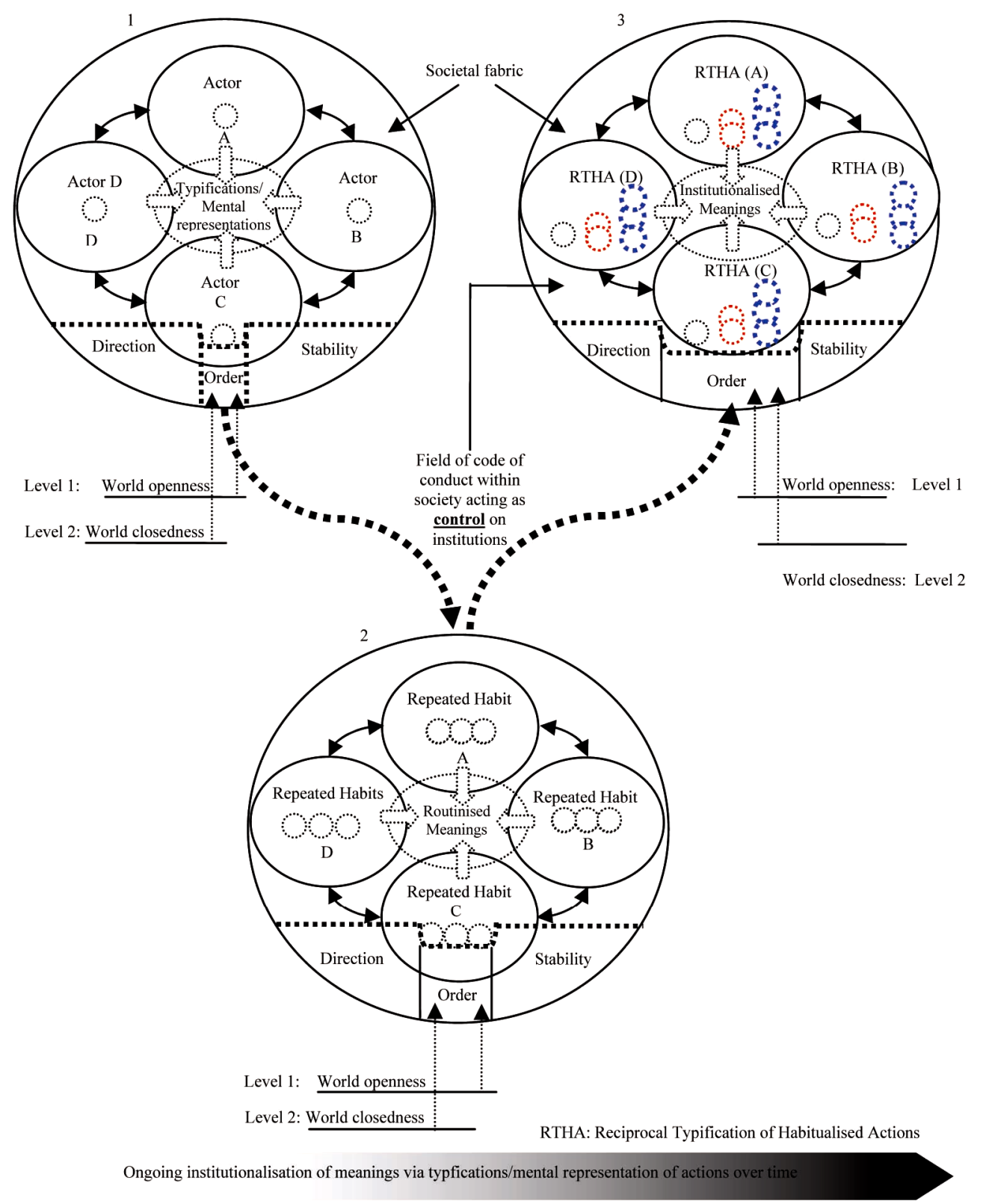

Figure 4. Institutionalisation of meanings via typification of habitualised actions

Designed by author but developed based on Berger and Luckmann's (1966) work

Stage six: institutions develop through historicity and behavioural control: ongoing reciprocal typifications of action are developed over a period of time and not instantaneously. All institutions have a prolonged history, which produce them over time (see Figure 5 below). Berger and Luckmann (1966) averred that institutions (or human actions) are controlled by human conduct through code of conduct. 


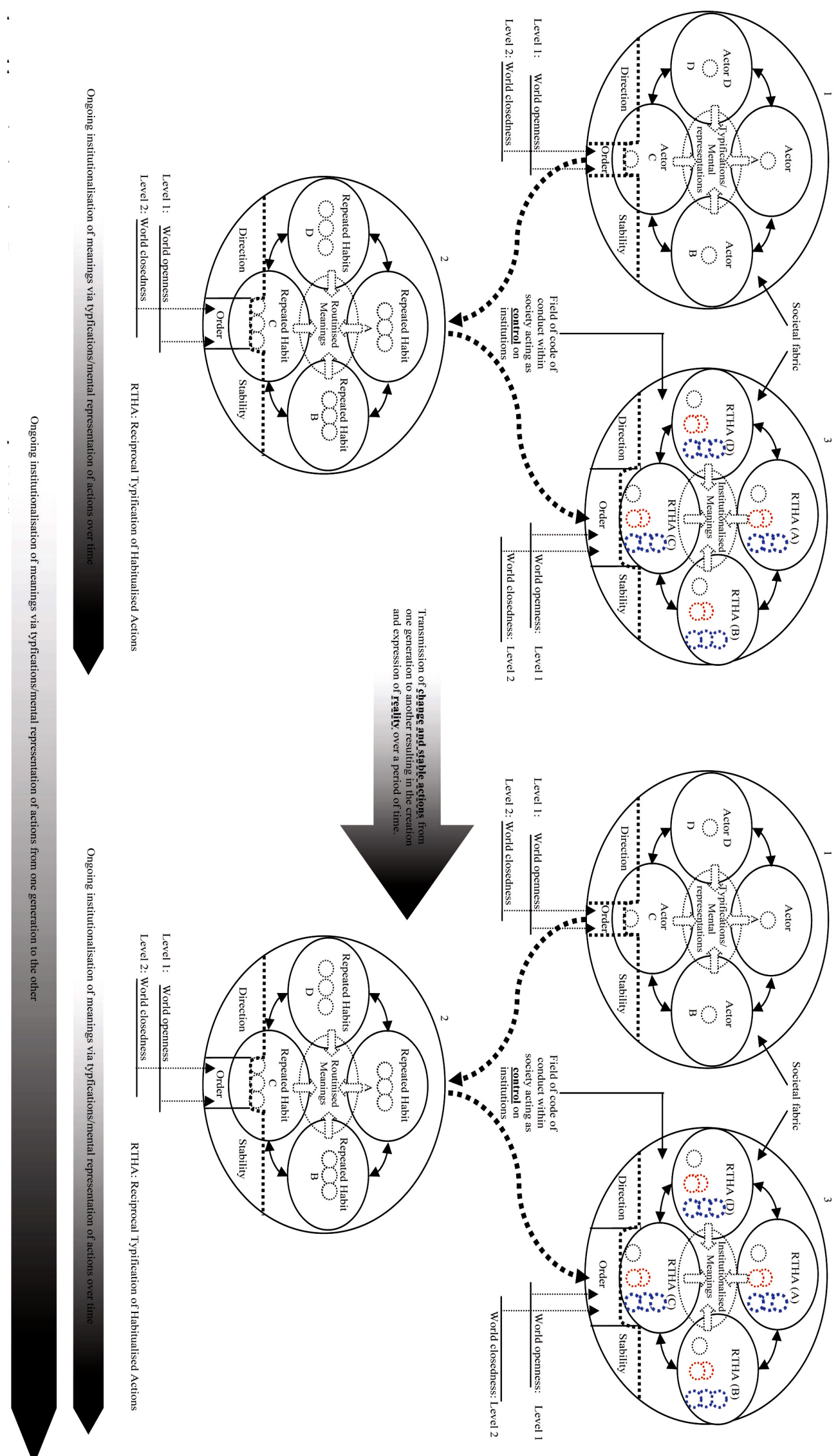

Figure 5. History and control 
Stage seven: Ongoing transmission of stable or changed actions resulting in the creation of reality: the shaping of the world is an ongoing activity that is fully transparent to those who originally carried out specific actions. The originators of such actions understand these actions fully and therefore the ability to change or abolish these practices (which might have been stable over a prolonged period of time) lies within their will power and authority. These actors are capable of changing, stabilising and transmitting these actions continuously to upcoming generations. For parents who witnessed the making of these actions, these activities become real. Although, these actions are opaque to new generations of children it is nevertheless perceived as "the real world" and it confronts such children as the reality.

\subsection{Conceptual Issues Emerging from Berger and Luckmann's (1966) Epistemology}

First, the production of the human environment is a joint and ongoing effort achieved based on interactions between at least two actors within the society. Second, social order (i.e. facets of society, which remain relatively consistent over time) is a product of ongoing human production. Third, meaning develops from ongoing Habitualisation: all human actions that are repeated regularly and recurrently over a period of time become cast into a behavioural pattern - and this become a habit. Meaning emanates from the regular, continued and prolonged repetitive nature of these actions. Fourth, institutionalisation emerges from ongoing reciprocal typified habitual action by social actors overtime. Reciprocal typifications are institutions, which emerge in different forms. Fifth, historiocity which is grounded in reciprocal typifications of action are developed ongoingly over a period of time and not instantaneously. All institutions have a history, which produce them over a prolonged period of time from year to year. Sixth, institutions control human conduct continuously through codes of conduct, which impinge on human conduct. Seventh, ongoing transmission of stable or changed actions results in the creation of reality. The concepts dominate Berger and Luckmann's (1966) social constructionist epistemology.

\section{Corporate Identity}

The previous paragraphs addressed the meaning of social construction together with Berger and Luckmann's (1966) epistemological process. This section builds on this by examining the meaning of corporate identity as well as various corporate identity formation process models. A variety of corporate identity models are reviewed in this paper because there is no definitive corporate identity formation process model (Suvatjis and de Chernatony, 2005) nor is there a universal or influential model as it is in the field of social construction. The review of these models should give a precise insight into how corporate identity is formed.

\subsection{Corporate Identity: What It Means}

The majority of the first set of literatures that emerged on the meaning of the concept of corporate identity in the 1970s up until the mid 1980 conceived corporate identity principally from symbolism perspectives (Alessandri, 2001; Balmer, 2001). This is not surprising given the graphic and design background of majority of these authors (van Riel and Balmer, 1997). For instance, a well known definition of corporate identity positioned the concept as firms' visual representation of what it is (Selame and Selame, 1975). Between the mid and late 1980s corporate identity became synonymous with corporate distinctiveness. Tanenberger (1987); Ackerman (1988); Lambert (1989) argued that corporate identity reflects the distinctive capability, which makes a firm's characteristics recognisable. The mid 1990s witnessed a shift in the meaning of the concept towards a multidisciplinary notion (Melewar and Jenkins, 2002; Balmer, 1998). This period represents the decade in which numerous definitions emerged from several business and non business disciplines (Balmer, 2001).

\subsection{Corporate Identity Formation Process}

There is a lack of a definitive corporate identity formation process (Suvatjis and de Chernatony, 2005) that can be used to underpin Berger and Luckmann's (1966) social construction process. In order to overcome this challenge, a typology of models (i.e. environmental, corporate personality, mission, strategy and communication driven models) based on the deconstruction of existing corporate identity models (Kennedy, 1977; Dowling, 1986; Abratt, 1989; van Riel and Balmer, 1997; Marwick and Fill, 1997; Stuart, 1998, 1999; Alessandri, 2001; Melewar and Woodridge, 2001; Suvatjis and de Chernatony, 2005), is proffered in the paragraphs that follow. These typologies are valuable in that they provide clearer understanding of arguments proposed in all the models It highlights the mandatory presence of major and minor components of these models. Furthermore, the typology provides a framework of interrelationships subsisting among the components of the models.

Environment driven models (see Kennedy, 1977; van Riel and Balmer, 1997; Melewar and Wooldridge, 2001; Suvatjis and de Chernatony, 2005) recognise the shaping of corporate identity through the business environment as well as a joint, interactive and ongoing process. Three key arguments are observed in these models. First is 
that the formation of corporate identity is an exercise achievable through ongoing interactions between two actors namely corporate actors (who act on behalf of the firm) and stakeholders (who make meanings of interactions and exert a myriad of extraneous influences) on firms. Second, ongoing expressions of multiple corporate personality (i.e. corporate policy, Kennedy, 1977; corporate behaviour, Melewar and Wooldridge, 2001; culture, history, van Riel and Balmer, 1997; corporate strategy, Suvatjis and de Chernatony, 2005) are expressed through employee behaviour (Kennedy, 1977), communication (Melewar and Wooldridge), creativity (Suvatjis and de Chernatony, 2005) or the corporate identity mix (van Riel and Balmer, 1997). Third, consistent expression of corporate personality through these medium generate multiple interpretations (Kennedy, 1977) and meanings among stakeholders of business organizations.

Corporate personality driven models: Unlike environment driven models, which is heavily reliant on ongoing interactions between corporate actors and stakeholders, corporate personality driven models (see Abbrat, 1989; Stuart, 1998, 1999) rely mainly on the conceptualisation and articulation of the constituents of corporate personality (i.e. corporate philosophy, core values, corporate culture, strategy, mission, objectives, Abratt, 1989; Stuart, 1998, 1999) as the foundation of the corporate identity formation process. Two important conceptualizations emerged from these models. First, the models address the consistent articulation and ongoing expression of multiple corporate personalities (i.e. a synopsis of 'what the firms is', 'what it is to do', 'what it is to achieve' and 'how to achieve its objectives', Abratt, 1989) to stakeholders through employee behaviour, symbolism, communication, marketing communications or corporate identity mix (Abratt, 1989; Stuart, 1998, 1999). Second, the models emphasise the transformation of corporate personalities into corporate image or reputation (Abratt, 1989; Stuart, 1998, 1999) through ongoing stakeholder mental processing and consistent interaction between corporate actors and stakeholders.

Mission driven models: mission driven models (see Baker and Balmer, 1997; Alessandri, 2001) promote the articulation of the corporate mission as the basis of corporate identity formation process. Baker and Balmer's (1997) and Alessandri's (2001) corporate image/corporate identity interface model addresses the relationship between corporate identity and corporate image and how this relationship aids the acquisition of a favourable corporate reputation. Mission driven models are founded on three theoretical assumptions. First is that corporate missions are translated into a combination of corporate personality (Baker and Balmer, 1997) and corporate identity (Baker and Balmer, 1997; Alessandri, 2001) through corporate culture, visual presentation and corporate behaviour (Baker and Balmer, 1997; Alessandri, 2001). Second, communicated identity or corporate reality (Baker and Balmer, 1997) is translated into corporate image or reputation (Alessandri, 2001) through stakeholder mental decision making process. Third, corporate identity and corporate image or reputation emerges from ongoing interaction between corporate actors and stakeholders.

Communication driven model: Dowling (1986) provides the only communication driven model. The model articulates how corporate policies impacts on corporate strategy and culture. Unlike Kennedy's (1977) model, which failed to address corporate identity communications, Dowling's (1986) model underscored the importance of various aspects of corporate communications (i.e. internal and marketing media communication) within the corporate identity formation process. Dowling (1986, p. 111) argued that "while interpersonal communication represents the images of the firm held by these groups, mass media communication represents the company's perception of itself". Two important conceptualisations can be derived from Dowling's (1986) model. First, formal corporate policies, which constitute the bulk of corporate personality, are communicated through culture, external interpersonal communications, previous product experience and distributors etc to create meanings or corporate image. Second, the notion of corporate identity, image and reputation emerges based on a myriad of ongoing corporate communication activities.

Strategy driven model: the strategy driven model is hinged on the conceptualisation and implementation of corporate strategy. The corporate strategy in Marwick and Fill's (1997) view is germane to the development of corporate personality, which in essence is deeply rooted in a variety of corporate activities. The model advocated the use of van Riel's notion of corporate communications, composed of management, organisational and marketing communications. The key thesis in Marwick and Fill's (1997) model is that while management communications transforms a firm's corporate personality into corporate identity, planned and unplanned organisational and marketing communications translate corporate identity into corporate image or reputation. In addition, Marwick and Fill's (1997) model promoted the need to fully consider ongoing environmental influences (see Kennedy, 1977) as a significant factor impinging on the translation of corporate identity into corporate image. Corporate identity and corporate image or corporate reputation emerges through strategic management from ongoing interaction between corporate actors and stakeholders. 


\subsection{Emerging Issues in Corporate Identity Formation Process Models}

The review of deconstruction of corporate identity models has triggered the emergence of seven conceptual issues. These are discussed in the paragraphs below:

Corporate identity as the outcome of ongoing interaction between actors in the environment: Corporate identity cannot emerge by itself. It is a collaborative social exercise emerging from ongoing interactions between corporate actors (who act of behalf of the firm) and stakeholders whose activities impinge severely on the business environment (Kennedy, 1977). Environment driven models (see Kennedy, 1977; van Riel and Balmer, 1997; Melewar and Wooldridge, 2001; Suvatjis and de Chernatony, 2005) lay emphasis on the ways that corporate identity is shaped through joint and ongoing interactions between firms and stakeholder in the business environment.

Consistent expression of corporate identity: The deconstruction of corporate identity models reveals that the expression of corporate personality is a consistent and ongoing social exercise. Constant and regular expression of corporate personality shapes corporate identity and stakeholder perception of the firm. Environmental led models (especially Kennedy's 1977 model) articulate and emphasise the consistent expression of corporate identity.

Meanings are generated and embedded in stakeholder interpretation of corporate identity and corporate personality: Meanings are generated from stakeholder perceptions of corporate personality or corporate identity. All the models classified into various categories (i.e. environment, corporate personality, mission, communication and strategy) in the paragraph above lay a strong emphasis on the transformation of corporate personality to corporate image and corporate reputation. Corporate image and corporate reputation evolve following ongoing interpretations and meanings made of corporate identity by stakeholders.

Multiple personalities triggers multiple corporate identity, corporate image and corporate reputation: The concepts of corporate mission, philosophy, culture, value, goals, objectives, history, which addresses issues about 'what the firm is', 'what the firm is to do', 'how it shall operate', 'how it shall be known' form the bulk of a firm's corporate personality (Abratt, 1989). Environmental led models (see Kennedy, 1977); corporate personality led models (Abratt, 1989; Stuart, 1998, 1999) and Mission led models (Baker and Balmer, 1997; Alessandri, 2001) address ongoing and concurrent expression of a variety of corporate personality, corporate identity, corporate image and reputation.

Corporate identity emerges from corporate history: Corporate identity emerges not only from the corporate mission, vision, philosophy etc but also by taking into account the historical roots. van Riel and Balmer (1997) environment led model expresses the development of corporate identity based on the articulation of corporate history and communication of monumental corporate events.

Corporate personality and identity as concepts that resides under the full control of the firm: Corporate mission, vision, objectives, culture, philosophy, goals, objective which forms the bulk of a firm's corporate personality and the corporate identity, lies under the full control of the firm. Evidence from the deconstruction of corporate mission led models (Alessandri, 2001 and Baker and Balmer, 1997) indicates that firms are capable of organising, re-organising, and directing their corporate identity and corporate personality as they deem fit.

Changing and stable personality results in corporate reality: the review of corporate mission led models (see Alessandri, 2001) indicate that firms drive and control corporate mission and other elements of corporate personality (i.e. vision, objectives, goals etc) in response to the ongoing changes and stable nature of environmental influences. Consequently, responses to stability and ongoing changes are expressed through the corporate identity mix. Thus, these expressions result in the formation of stable and changing corporate identity. The stability and the changes witnessed in the corporate identity formations process are reflective of what is real about the firm at any point in time. It is an indication of what mission led models (see Baker and Balmer, 1997) refer to or describe as the corporate reality.

\subsection{Linking Social Construction Epistemology and Corporate Identity Formation Models}

The review of Berger and Luckmann's (1966) social constructionist epistemology (1966) together with a variety corporate identity models provide evidence to suggest that these disciplines are fundamentally connected. Thus, it is possible to locate areas in which social constructionism and corporate identity interrelate. This claim is based on the evidence that many of the key insights emerging from the review of literature (above) are compatible and can therefore be integrated. The author makes an attempt to integrate these two concepts by bringing together key issues within them. These points are highlighted below:

First point of connection: Joint and ongoing production of the human environment: man alone cannot 
produce the human environment. The successful production of the human environment can only be achieved based on ongoing interactions between at least two actors within the society. The collaborative nature of human production is not limited to the social sciences. It is also an important aspect of corporate identity studies. The successful development of corporate identity is hinged on a joint and collaborative effort achieved through the ongoing interaction of corporate actors (acting on behalf of the firm) and stakeholders (Kennedy, 1977) whose activities influence the environment.

Second point of connection: Consistent nature of social order: the production of the human environment by actors relies heavily on the consistent nature of social order. Social order is a human product reflective of ongoing human production. It is produced by man in the course of man's ongoing externalisation and derived from past human activity. In the same vein, corporate identity is an ongoing exercise. It is produced consistently (Kennedy, 1977; Marwick and Fill, 1997) by corporate actors acting on behalf of the firm. The ongoing and consistent production of corporate identity by corporate actors can be witnessed through organisational growth, diversification merger and acquisition and consolidate exercises (Alessandri, 2001). Thus, as firms change and consolidate their business activities, the production of corporate identity by corporate actors' is done consistently. It is produced continuously to represent ongoing stability and change exercised by firms.

Third point of connection: meaning through consistent and ongoing actions and expressions: Berger and Luckmann (1966) argued that when repeated frequently, all human actions become cast into a pattern and that in the course of these repetitions, human activity become habitualised. Importantly, meanings emanate from regular, continued and ongoing repetitive nature of these actions. Berger and Luckmann's (1966) epistemology of generating meanings through habitualisation is not limited to sociological studies. This notion also holds true within the corporate identity literature (see Figure 6). Meanings emerge from regular, ongoing (Marwick and Fill, 1997) expression of corporate identity. When corporate identity is expressed consistently (or repeatedly) over a prolonged period of time, it becomes a pattern (Moingeon and Ramanantsoa, 1995a) which becomes habitualised overtime.

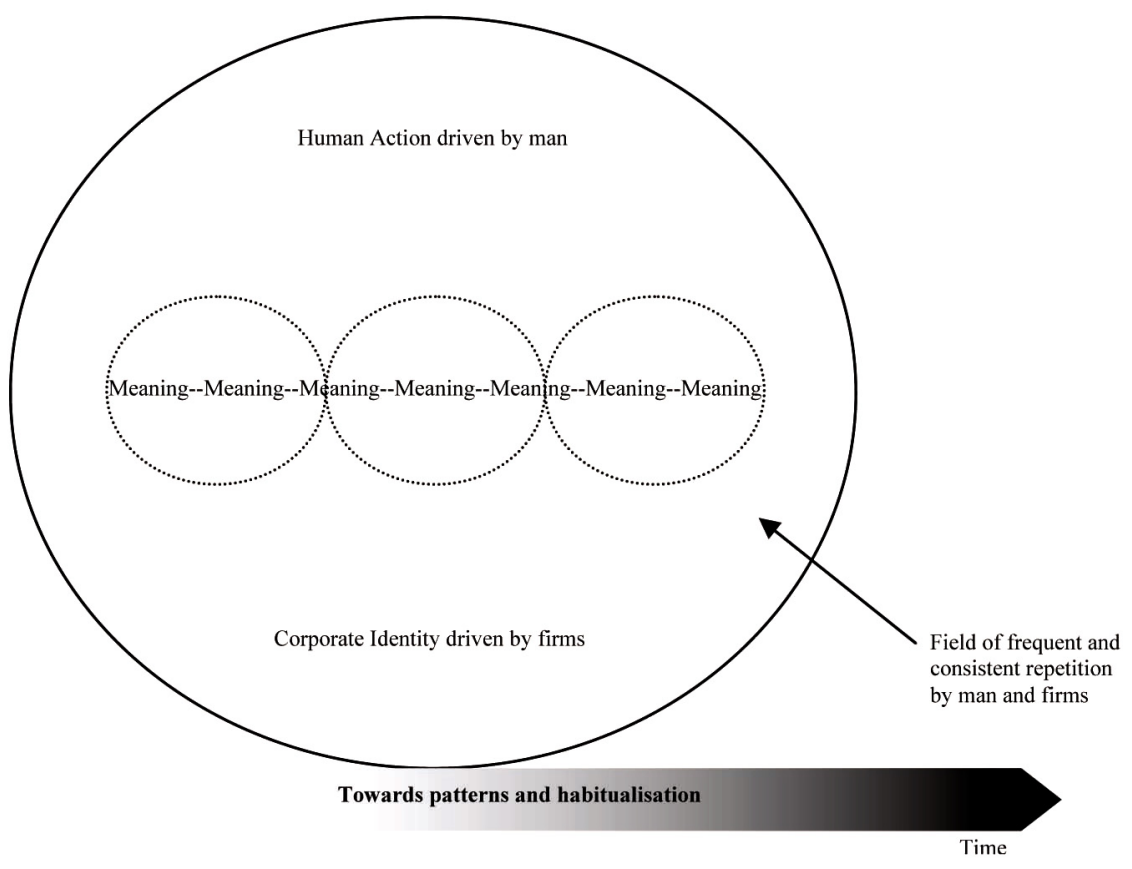

Figure 6. Meaning emerging from regular, consistent, prolonged repetitive actions

Developed by author

The need to be consistent (or repetitive) in the implementation of corporate identity programmes has been emphasised in literature. For instance, Marwick and Fill (1997) advocated the need to pursue repetitive and sustainable internal identity in order to express a positive corporate identity to stakeholders. Thus, meanings are generated from stakeholder encounters with corporate identity (Marwick and Fill, 1997). Meanings will develop from the outcome of all interactions between firms and stakeholders as well as from all stakeholder experiences, 
beliefs, feelings, knowledge and impressions of the firm (Bernstein, 1984).

Fourth point of connection: Variety of actions and corporate identity emerging from ongoing reciprocal typifications: institutionalisation emerges from ongoing Reciprocal Typified Habitual Actions (RTHA). The notion of RTHA (which in essence constitute institutions) refers to all types of habits and habitual actions that are developed and shared based on consistent and ongoing interactions among actors. Similarly, institutionalisation occurs within the framework of corporate identity when a variety of shared actions materialise based on consistent and ongoing interactions between corporate actors (acting on behalf of firms) and stakeholders. In essence, the notion of institutionalisation occurs in corporate identity when a variety of interpretations are generated habitually from the consistent expression of a multiple of corporate identities (Marwick and Fill, 1997).

Fifth point of connection: History of actions emerging from ongoing reciprocal typifications: when Reciprocal Typified Habitual Actions (RTHA) are repeated and prolonged over a long period, they accumulate into history. All institutions have a history of which they are the products. The history of shared RTHA cannot be created instantaneously. A series of activities has to be created repeatedly over a long period of time and in some cases passed from one generation of actors to another. It is thorough these activities that history is created. Similarly, when Reciprocal Typified Habitual Actions (RTHA) is repeated over a long period (via the repetitive expression of corporate identity) a corporate identity history is agglomerated. This is clearly demonstrated in years one, two, three and four of Figure 7. Essentially, the expression of corporate identity over a long period becomes a product of corporate history (Moingeon and Ramanatsoa, 1997). This makes the concept of corporate identity to be tightly connected to the concept of history. A robust corporate identity emerges by taking into account the firm's history (van Riel and Balmer, 1997).
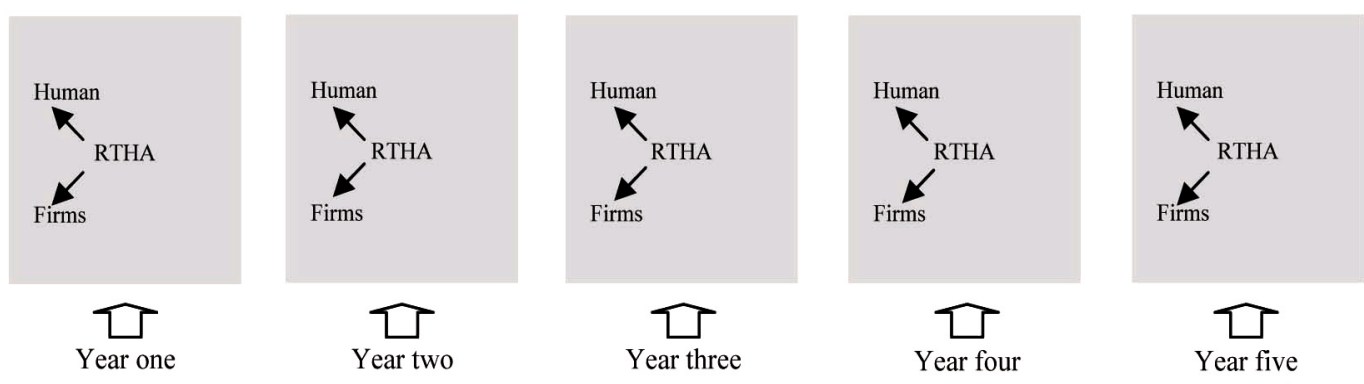

History unfolding over time

Figure 7. History of actions

Sixth point of connection: Continuous control of actions and business activities: human conduct is controlled continuously by a predefined set of codes of conduct - and it is these rules and regulations that channel human conduct towards a specific direction. Firms control their corporate identity through effective management of their mission, vision, strategy, culture, core values, philosophy and strategic objectives. The ongoing control measures set by firms inevitably influences the nature corporate identity (Alessandri, 2001).

Seventh point of connection: ongoing communication of stable and changing actions/business activities and the emergence of corporate reality: actors produce stable and changed actions collaboratively through shared ongoing interactions (within the society). These are transmitted from one generation to another. In the process, reality about the world is created. Firms equally stabilise and adjust their corporate identity through the effective management of their corporate personality including vision, mission, culture, values etc (Alessandri, 2001). The stability and changing aspects of corporate identity is expressed through corporate identity mix (van Riel and Balmer, 1997). Consequently, these expressions result in the construction of reality or what Abratt (1989) described as what the firm is.

\subsection{Ongoing: The Major Point of Integration}

One major and domineering theme running through the seven points of interconnectivity presented above is the notion of 'ongoing'. The Oxford Advanced Learner's Dictionary (2000) defines 'ongoing' as a state in which a 
phenomenon continues with no cease. It could be inferred from this definition therefore that the concept of 'ongoing' as applied in Berger and Luckmann's (1966) thesis addresses the evolution, development, continuum and never ending actions and interactions that take place among social actors or between firms and stakeholders. It is a major underlying force and a key ingredient responsible for the production and activation of the habitualisation and eventual institutionalisation of human and corporate actions (which continues without end). The notion of 'ongoing' set-forth a never-ending set of interactions between people and the society or between firms and stakeholders. This inadvertently results in the habitualisation and institutionalisation of the actions and interactions between people and society as well as firms and stakeholders. The key philosophy that underpins this theory is that it provides the underlying forces through which movement or change from one condition to another occurs with no cease. It is a representation of how human and corporate actions and interactions develop, change and move cohesively, logically and sequentially; step by step; from the simple to a more complex state, with no cease. In essence, without the concept of 'ongoing', the institutionalisation of human and corporate actions may never be achieved.

\section{Conclusion}

This paper sought to embed the concept of corporate identity with a social science theory. In doing so, the paper offered the social constructionist theory as a lens for approaching the concept. Importantly, three important contributions emerged from this study. The first gives an introduction insight into Berger and Luckmann's complex social constructionist theory by breaking it down into a seven development process stages namely joint and ongoing production of the human society; the use of social order over time; and the development of meaning from ongoing Habitualisation. Other include the emergence of institutionalisation through ongoing reciprocal typified habitual action overtime; historiocity; control of human conduct ongoignly and the ongoing transmission of stable or changed actions. The second finding drew attention to the presence of a typology of models (i.e. environmental, corporate personality, mission, strategy and communication driven models), which unknown to authors, dominate existing corporate identity literature. The third contribution in this paper provides a synthesis, which finally embeds social constructionist theory into the field of marketing.

This study is unique. This is because existing works on corporate identity (see for instance Suvatjis and de Chernatony, 2005; Kennedy, 1977; Dowling, 1986; Abratt, 1989; van Riel and Balmer, 1997; Marwick and Fill, 1997; Stuart, 1998; Stuart, 1999; Alessandri, 2001; Melewar and Woodridge, 2001; Suvatjis and de Chernatony, 2005) emerged primarily from positivistic mindsets. As such majority of these works, if not all, is bereft of a strong social science theory. Consequently, the attempt in this paper to provide corporate identity with social science grounding makes this paper valuable. The implication of this paper, especially for theorists is that it sets a new platform and channels a new direction in theory development for the concept of corporate identity. It encourages researchers to leap beyond the positivistic tradition into other traditions that can engender greater understanding of corporate identity.

\section{References}

Abratt, R. (1989). A new approach to the corporate image management process. Journal of Marketing Management, 5(1), 63-76. http://dx.doi.org/10.1080/0267257X.1989.9964088

Ackerman, L. D. (1988). Identity strategies that make a difference. The Journal of Business Strategy, May/June, 28-32. http://dx.doi.org/10.1108/eb039224

Alessandri, S. (2001). Modelling corporate identity: a concept explication and theoretical explanation. Corporate Communications: An International Journal, 6(4), 173-182. http://dx.doi.org/10.1108/EUM0000000006146

Baker, M. J., \& Balmer, J. M. T. (1997). Visual identity: Trappings or Substance? European Journal of Marketing, 31(5-6), 366-382.

Balmer, J. M. T. (1998). Corporate identity and advent of corporate marketing. Journal of Marketing Management, 4, 963-996. http://dx.doi.org/10.1362/026725798784867536

Balmer, J. M. T. (2001). Corporate identity, corporate branding, and corporate marketing: seeing through the fog. European Journal of Marketing, 34(3\&4), 248-291. http://dx.doi.org/10.1108/03090560110694763

Banister, P., Burman, E., Parker, I., Taylor, M., \& Tindall, C. (1994). Qualitative Methods in Psychology: A Research Guide. Buckingham: Open University Press.

Bayer, B. M., \& Shotter, J. (1998). Reconstructing the psychological subject: Bodies, practices and technologies. London: Sage. 
Berger, P., \& Luckmann, T. (1966). The Social Construction of Reality: A Treatise in the Sociology of Knowledge.

Bruner, J. (1990). Acts of meaning. Cambridge, MA: Harvard University Press.

Dowling, G. R. (1986). Managing your corporate image. Industrial Marketing Management, 15, 109-15. http://dx.doi.org/10.1016/0019-8501(86)90051-9

Edvardsson, B., Tronvoll, B., \& Gruber, T. (2011). Expanding understanding of service and value co-creation: a social construction approach. Journal of the Academy of Marketing Science, 39(2), 327-339. http://dx.doi.org/10.1007/s11747-010-0200-y

Edwards, D., \& Porter, J. (1992). Discursive psychology. London: Sage.

Fairclough, N. (1995). Critical discourse analysis: The critical study of language. London: Longman.

Fox, D., \& Prilleltensky, I. Critical psychology: An introduction. London: Sage.

Gergen, K. J. (2010). Realities and Relationships: Soundings in Social Construction. Cambridge, MA: Harvard University Press.

Gupta, K. (2001). Tourism in New Caledonia: Social Construction and Marketing of Images. Indiana University Working Papers.

Hackling, I. (2010). The Social Construction of What? Harvard University Press.

Hall, S. (1999). Representation: Cultural Representations and Signifying Practices. Thousand Oaks, Londo: Sage Publications.

Harre, R., \& Gillett, G. (1994). The discursive mind. Thousand Oaks, Sage, CA.

Kennedy, S. H. (1977). Nurturing Corporate Images: total communication or ego trip? European Journal of Marketing, 11(3), 120-164.

Lambert, A. (1989). Corporate identity and facilities management. Facilities, 7(12), 7-12. http://dx.doi.org/10.1108/eb006515

Marwick, N., \& Fill, C. (1997). Towards a framework for managing corporate identity. European Journal of Marketing, 31(5/6), 396-409. http://dx.doi.org/10.1108/eb060639

Matsui, T. (2009). The Social Construction of Consumer Needs: A Case Analysis of the "Healing Boom" in Japan. Advances in Consumer Research.

Melewar, T. C., \& Jenkins, E. (2002). Defining the corporate identity construct. Corporate Reputation Review, 5(1), 76-90. http://dx.doi.org/10.1057/palgrave.crr.1540166

Melewar, T. C., \& Wooldridge, A. (2001). The dynamics of corporate identity: a review of a process model. Journal of Communication Management, 5, 327-340. http://dx.doi.org/10.1108/13632540110806866

Miller, P. J., \& Hoogstra, L. (1992), Language as tool in the socialization and apprehension of cultural meaning. In T. Schwartz, G.M. White, and C.A. Lutz (Eds.), The social life of psyche: debates and directions in psychological anthropology. Cambridge: Cambridge University Press.

Morgan, N., \& Pritchard, A. (1998). Creating and consuming the image in tourism promotion and power: creating images, creating identities. NY: John Wiley and Sons.

Orlitzky, M. (2011). Institutional logics in the study of organizations: the social construction of the relationship between corporate social and financial performance. Business Ethics Quarterly, 21(3), 409-444. http://dx.doi.org/10.5840/beq201121325

Palmer, A., \& Ponsonby, S. (2001). The social construction of new marketing paradigms: the influence of personal perspective. Journal of Marketing Management, 18, 173-192. http://dx.doi.org/10.1362/0267257022775864

Potter, J. (1998). Discursie social psychology: from attitudes to evaluations. European Review of Social Psychology, 9, 233-266. http://dx.doi.org/10.1080/14792779843000090

Potter, J., \& Wetherell, M. (1987). Discourse and social psychology: beyond attitudes and behavior. London: Sage.

Searle, J. R. (1995). The construction of social reality. Free Press.

Selame, E., \& Selame, J. (1975). The Company Image. New York: John Wiley and Sons. 
Shotter, J. (1993a). Cultural Politics of Everyday Life: Social Constructionism, Rhetoric and Knowing of the Third Kind. Milton Keynes: Open University Press.

Shotter, J. (1993b). Conversational Realities: The Construction of Life through Language. London: Sage.

Stuart, H. (1998). Exploring the corporate identity/corporate image interface: an empirical study of accountancy firms. Journal of Communication Management, 2(4), 357-71. http://dx.doi.org/10.1108/eb023476

Stuart, H. (1999). Towards a definitive model of the corporate identity management process. Corporate Communications: an International Journal, 4(4), 200-207. http://dx.doi.org/10.1108/13563289910299328

Suvatjis, J. Y., \& De Chernatony, L. (2005). Corporate identity modelling: a review and presentation of a new multi-dimensional model. Journal of Marketing Management, 21(7), 809-834. http://dx.doi.org/10.1362/026725705774538480

Tannebeger, A. (1987). Corporate Identity: Studie Zur Theoretischen Fundierung. und Präzisierung der Begriffe.

Van Riel, C. B. M., \& Balmer, J. M. T. (1997). Corporate identity: the concept, its measurement and management. European Journal of Marketing, 31(5\&6), 340-355.

Witt, U. (2010). Symbolic consumption and the social construction of product characteristics. Structural Change and Economic Dynamics, 21(1), 17-25. http://dx.doi.org/10.1016/j.strueco.2009.11.008

Wu, H. (2009). The construction of a consumer population in advertising in 1920s China. Discourse and Society, 20(1), 147-171. http://dx.doi.org/10.1177/0957926508095893 